\title{
PENGARUH DISPLIN, BUDAYA ORGANISASI, DAN MOTIVASI KERJA TERHADAP LOYALITAS KARYAWAN PADA PT PELITA CENGKARENG PAPER
}

\author{
Sutarya \\ Alumni Program Manajemen S1 \\ Sekolah Tinggi Ilmu Ekonomi Bisnis Indonesia, Jakarta \\ Dan \\ Meslo Pardede \\ Dosen STIE Bisnis Indonesia, Jakarta
}

\begin{abstract}
The influence of this study aims to analyze and with the help of SPSS version 23. the results of test analysis, known value t count $>$ ttable that is equal to 2,849>1,984 with significance 0.005, so the decision taken is Ho rejected and Ha accepted. These results indicate that the discipline partially gives a significant influence on employee loyalty at PT Pelita Cengkareng Paper. Based on the result of t test analysis, it is known that t count $<$ ttable is 1,147 <1,984 with significance 0,254, so decision taken is Ho accepted and Ha rejected. These results indicate that the partial assessment has no significant effect on employee loyalty to PT Pelita Cengkareng Paper. Based on the result of t test analysis, it is known that tcount $>$ ttable is 3,398> 1,984 with significance 0,001, so decision taken is Ho rejected and Ha accepted. These results indicate that motivation partially significant effect on employee loyalty at PT Pelita Cengkareng Paper. Based on the result of F test analysis, it is known that Fcount $>$ Ftable $(8,721>2,474)$ with significance value 0,000, so the decision taken is Ho refused and Ha accepted. These results indicate that all independent variables (discipline, environmental culture and motivation) influence simultaneously or together to employee loyalty to PT Pelita Cengkareng Paper.
\end{abstract}

Keywords: Discipline, environmental culture, motivation and employee loyalty

Abstrak: Tujuan penelitian ini bertujuan untuk menganalisis dan dengan bantuan SPSS versi 23. hasil analisis uji t, diketahui nilai $t_{\text {hitung }}>t_{\text {tabel }}$ yaitu sebesar 2,849 $>1,984$ dengan signifikansi 0,005, sehingga keputusan yang diambil adalah Ho ditolak dan Ha dierima. Hasil ini menunjukkan bahwa kedisiplinan secara parsial memberikan pengaruh signifikan terhadap loyalitas karyawan pada PT Pelita Cengkareng Paper.Berdasarkan hasil analisis uji t, diketahui nilai $\mathrm{t}_{\text {hitung }}<\mathrm{t}_{\text {tabel }}$ yaitu sebesar 1,147 $<1,984$ dengan signifikansi 0,254, sehingga keputusan yang diambil adalah Ho diterima dan Ha ditolak. Hasil ini menunjukkan bahwa penilaian secara parsial tidak berpengaruh signifikan terhadap loyalitas karyawan pada PT Pelita Cengkareng Paper. Berdasarkan hasil analisis uji t, diketahui nilai $t_{\text {hitung }}>t_{\text {tabel }}$ yaitu sebesar 3,398 $>1,984$ dengan signifikansi 0,001, sehingga keputusan yang diambil adalah Ho ditolak dan Ha diterima. Hasil ini menunjukkan bahwa motivasi secara parsial berpengaruh signifikan terhadap loyalitas karyawan pada PT Pelita Cengkareng Paper. Berdasarkan hasil analisis uji $\mathrm{F}$, diketahui Fhitung $>$ Ftabel $(8,721>2,474)$ dengan nilai signifikansi 0,000 , sehingga keputusan yang diambil adalah Ho ditolak dan Ha diterima. Hasil ini menunjukkan bahwa seluruh variabel bebas (kedisplinan, budaya lingkungan dan motivasi) berpengaruh secara simultan atau bersama-sama terhadap loyalitas karyawan pada PT Pelita Cengkareng Paper.

Kata Kunci: Kedisiplian, budayalingkungan, motivasidanloyalitaskaryawan. 


\section{Pendahuluan}

Sumber daya manusia merupakan arti penting dari suatu realita bahwa setiap individu manusia merupakan elemen yang paling utama karena selalu ada dalam suatu organisasi. Sumber daya terpenting suatu perusahaan atau organisasi adalah sumber daya manusia yaitu orang yang telah memberikan tenaga, bakat, kreatifitas dan usaha mereka kepada organisasi. Masalah sumber daya manusia menjadi sebuah tantangan bagi manajemen, karena keberhasilan perusahaan tergantung dari kualitas sumber daya manusia yang dimiliki/dipekerjakan. Hasibuan (2000:12), menyatakan bahwa "Manusia selalu berperan aktif dalam menentukan rencana, sistem, proses, tujuan yang ingin dicapai oleh perusahaan." Tujuan tidak mungkin terwujud tanpa peran karyawan meskipun dukungan sarana dan prasarana serta sumber dana yang dimiliki perusahaan tidak akan ada manfaatnya bagi perusahaan, jika peran aktif karyawan tidak diikut sertakan.

Hayes, dkk (2012:39) mendefinisikan "Perilaku karyawan di lingkungan kerja memiliki pengaruh yang tinggi terhadap produktivitas." Wibawa (2010) melakukan penelitian dengan judul. Pengaruh Kompenssai dan Budaya organisasi Pada Loyalitas Karyawan Berdasarkan Jenis Kelamain. Dengan hasil penelitian nya yaitu: Penelitian ini bertujuan untuk menguji pengaruh kompensasi dan budaya organisasi terhadap loyalitas karyawan berdasarkan jenis kelamin baik secara simultan maupun secara parsial. Berdasarkan hasil analisis ditemukan bahwa kompensasi dan budaya organisasi secara simultan berpengaruh signifikan terhadap loyalitas karyawan. Kompensasi secara parsial berpengaruh signifikan terhadap loyalitas karyawan. Budaya organisasi secara parsial tidak berpengaruh signifikan terhadap loyalitas karyawan.

Ketidakhadiran dan keterlambatan karyawan dalam bekerja dapat menyebabkan kinerja karyawan menurun. Hal ini dapat dijelaskan, bahwa jika karyawan tidak hadir atau terlambat dalam bekerja maka karyawan tersebut tidak mengikuti brifing secara utuh sehingga pembagian tugas yang dibebankan kepadanya akan terbengkalai atau tidak selesai sesuai dengan yang diharapkan. Keterlambatan hadir karyawan menyebabkan pelayanan nasabah terganggu dan terkadang seorang pegawai harus merangkap tugas sampai dengan karyawan tersebut datang. Sering terjadi karyawan yang datang terlambat mendapat sambutan yang kurang menyenangkan dari karyawan yang lain sehingga karyawan yang datang terlambat menjadi tidak maksimal dalam bekerja. Hal ini akan menimbulkan ketidak efektifan dan ketidak efisienan seseorang dalam bekerja dan lebih jauh lagi dapat menurunkan kinerja.

\section{Landasan Teori}

\subsection{Manajemen}

Wijayanti (2008:1) mengartikan "Manajemen adalah proses perencanaan, pengorganisasian, pengarahan, dan pengawasan usaha-usaha para anggota organisasi dan penggunaan sumber dayasumber daya manusia organisasi lainnya agar mencapai tujuan organisasi yang telah ditetapkan". Schein (2010:2) memberi definisi "Manajemen adalah suatu profesi yang dituntut untuk bekerja secara profesional, karakteristiknya adalah para professional membuat keputusan berdsarkan prinsip-prinsip umum, para professional mendapatkan status mereka karena mereka mencapai standar prestasi kerja tertentu, dan para profesional harus ditentukan suatu kode etik yang kuat".

\subsection{Disiplin}

Hasibuan (2003:213) mendefinisikan bahwa: "Disiplin harus ditegakkan dalam suatu organisasi perusahaan, karena tanpa dukungan disiplin karyawan yang baik, maka sulit bagi suatu perusahaan untuk mewujudkan tujuannya." Untuk lebih memahami konsep disiplin kerja, berikut ini adalah beberapa penjelasan yang berkaitan dengan disiplin kerja. Sinungan (2006:146) mengatakan bahwa "Disiplin kerja yaitu sikap mental yang tercermin dalam perbuatan atau tingkah laku perorangan, kelompok atau masyarakat berupa kepatuhan atau ketaatan (obedience) terhadap peraturan- 
peraturan yang ditetapkan baik oleh pemerintah mengenai etik, norma dan kaidah yang berlaku dalam masyarakat untuk tujuan tertentu. Berdasarkan pengertian-pengertian di atas dapat disimpulkan bahwa yang dimaksud dengan disiplin kerja adalah sikap mental yang tercermin dalam perbuatan perorangan maupun kelompok berupa kepatuhan atau ketaatan terhadap peraturanperaturan yang ditetapkan untuk memperteguh pedoman-pedoman organisasi.

\subsection{Budaya Organisasi}

Kehidupan manusia tidak terlepas dari berbagai keadaan lingkungan sekitarnya, antara manusia dan lingkungan terdapat hubungan yang sangat erat. Komarudin (2008:231), menyatakan bahwa "Budaya Organisasi adalah kehidupan sosial, psikologi, dan fisik dalam perusahaan yang berpengaruh terhadap pekerja dalam melaksanakan tugasnya”. Kehidupan sosial yang dimaksud berkenaan dengan keyakinan nilai-nilai, sikap, pandangan, pola atau gaya hidup di lingkungan sekitar serta interaksi antara orang-orang yang bekerja dalam suatu perusahaan baik itu interaksi antara atasan dengan bawahan maupun dengan rekan kerja. Kehidupan psikologis adalah interaksi perilaku-perilaku karyawan dalam suatu perusahaan dimana mereka bekerja. Setiap orang dalam suatu perusahaan membawa suatu harapan akan pemenuhan kebutuhan dan keinginan. Mangkunegara (2010:105), menyatakan bahwa "Budaya organisasi adalah semua aspek fisik kerja, psikologis kerja dan peraturan kerja yang dapat mempengaruhi kepuasan kerja dan pencapaian produktivitas".

\subsection{Motivasi}

Motivasi semakin penting karena manajer membagikan pekerjaan pada bawahannya untuk dikerjakan dengan baik dan terintegrasi kepada tujuan yang diinginkan. Perusahaan tidak hanya mengharapkan karyawan mampu, cakap dan terampil tetapi yang terpenting mereka memiliki keinginan untuk bekerja dengan giat dan mencapai hasil kerja yang baik. Handoko (2012:252) menyatakan bahwa "Motivasi adalah keadaan dalam pribadi seseorang yang mendorong keinginan individu untuk melakukan kegiatan-kegiatan tertentu guna mencapai tujuan." Selanjutnya Rivai (2008:457), mengatakan bahwa "Motivasi adalah suatu keahlian dalam mengarahkan karyawan dan perusahaan agar mau bekerja secara berhasil, sehingga keinginan karyawan dan tujuan perusahaan sekaligus tercapai."

\subsection{Loyalitas Karyawan}

Dalam melaksanakan kegiatan kerja karyawan tidak akan terlepas dari loyalitas dan sikap kerja, sehingga dengan demikian karyawan tersebut akan selalu melaksanakan pekerjaan dengan baik. Karyawan merasakan adanya kesenangan yang mendalam terhadap pekerjaan yang dilakukan. Utomo (2010:97) bahwa: "loyalitas dapat dikatakan sebagai kesetiaan seseorang terhadap suatu hal yang bukan hanya berupa kesetiaan fisik semata, namun lebih pada kesetiaan non fisik seperti pikiran dan perhatian". Menurut Sudimin (2009) bahwa: "loyalitas berarti kesediaan karyawan dengan seluruh kemampuan, keterampilan, pikiran, dan waktu untuk ikut serta mencapai tujuan organisasi dan menyimpan rahasia organisasi serta tidak melakukan tindakan-tindakan yang merugikan organisasi selama orang itu masih berstatus sebagai karyawan".

\subsubsection{Indikator Loyalitas Karyawan}

Pambudi (2010:91), juga menambahkan bahwa lima 5 faktor yang menjadi tolok ukur sumber daya manusia yang mempunyai loyalitas atau komitmen, yaitu:

1. Karyawan tersebut berada di organisasi tertentu.

2. Karyawan tersebut mengenal seluk beluk bisnis perusahaannya maupun para pelanggannya dengan baik. 
3. Karyawan tersebut turut berperan dalam mempertahankan hubungan dengan pelanggan yang menguntungkan bagi perusahaannya.

4. Karyawan tersebut merupakan aset tak berwujud yang tidak dapat ditiru oleh para pesaing.

5. Karyawan tersebut mempromosikan organisasinya, baik dari sudut produk, layanan, sebagai tempat kerja yang ideal maupun keunggulan kinerja dan masa depan yang lebih baik.

\subsection{Kerangka Pikir}

Dalam sumber daya manusia khususnya disiplin, budaya organisasi dan motivasi, banyak faktorfaktor yang mempengaruhi kendala tentang loyalitas karyawan. Dengan banyaknya kendala-kendala yang dihadapi PT Pelita Cengkareng Paper meningkatkan sumber daya manusia. Oleh karna itu kerangka pikir penelitian ini adalah sebagai berikut:

\section{Gambar 2.1}

\section{Skema Kerangka Pikir}

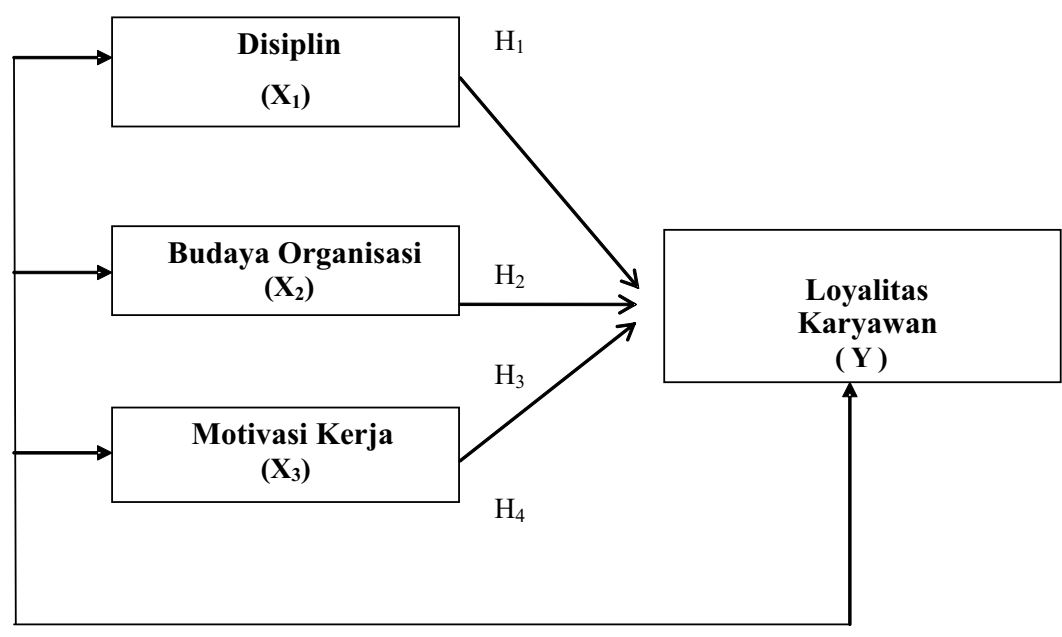

Sumber: Penulis (2017)

\subsection{Hipotesa}

Berdasarkan rumusan masalah di atas maka penulis mengajukan hipotesis sebagai berikut: Hipotesa 1

Ho : diduga tidak terdapat pengaruh signifikan disiplin terhadap loyalitas karyawan.

Ha1 : diduga terdapat pengaruh signifikan disiplin terhadap loyalitas karyawan.

Hipotesa 2

Ho :diduga tidak terdapat pengaruh signifikan budaya organisasi terhadap loyalitas karyawan.

$\mathrm{Ha} 2$ : diduga terdapat pengaruh signifikan budaya organisasi terhadap loyalitas karyawan.

Hipotesa 3

Ho : diduga tidak terdapat pengaruh signifikan motivasi kerja terhadap loyalitas karyawan.

Ha3 : diduga terdapat pengaruh signifikan motivasi kerja terhadap loyalitas karyawan.

Hipotesa 4

Ho : diduga tidak terdapat pengaruh signifikan disiplin, budaya organisasi, dan motivasi kerja secara bersama-sama terhadap loyalitas karyawan.

Ha4 : diduga terdapat pengaruh signifikan antara disiplin, budaya organisasi, dan motivasi kerja secara bersama-sama terhadap loyalitas karyawan. 


\section{Metodologi Penelitian}

\subsection{Metode Penelitian}

Metode adalah prosedur atau cara untuk mengetahui sesuatu, yang mempunyai langkah sistemaris. Penelitian pada umumnya bertujuan untuk mempunyai dan menemukan sesuatu masalah atau fenomena yang terjadi pada objek. Peneliti memilih objek penelitian pada PT Pelita Cengkareng Paper, yang berlokasi di Jl. Daan Mogot, Jakarta Barat.

\subsection{Populasi Dan Sampel}

\subsubsection{Populasi}

Hamidi (2007;126) dalam judul bukunya; Metode Penelitian dan Komunikasi, menyatakan bahwa: "populasi adalah keseluruhan satuan analisis (unit of analysis) yang hendak diteliti, dalam hal ini adalah individu-individu responden". Kemudian sesuai dengan permasalahan penelitian, Peneliti harus menetapkan kriteria populasi. Jika unit analisisnya individu, maka individu di lingkungan mana yang akan dijadikan populasinya. Dengan demikian tujuan menetapkan kriteria adalah untuk menentukan siapa yang memenuhi syarat untuk dijadikan responden dan siapa yang tidak memenuhi ketentuan persyaratan tersebut. Populasi dari penelitian ini 500 karyawan PT Pelita Cengkareng Paper.

\subsubsection{Sampel}

Menurut Sugiyono (2009:91) dalam judul bukunya; Metode Penelitian Bisnis, menyatakan bahwa: "sampel adalah bagian dari jumlah dan karakteristik yang dimiliki oleh populasi tersebut". Bila terdapat populasi yang besar dan peneliti tidak mungkin mempelajari semua yang ada pada populasi, misalnya karena keterbatasan dana, tenaga dan waktu, maka peneliti dapat menggunakan sampel yang di ambil dari populasi itu. Menurut Sarjono dan Julianita (2011:30) "ukuran dari sampel yang akan dijadikan objek penelitian ditentukan dengan pendekatan rumus slovin dengan persentase sampling error yang ditoleransi 10\%". Rumus slovin adalah sebagai berikut:

$$
\mathrm{n}=\frac{\mathrm{N}}{1+\mathrm{N} \cdot \mathrm{e}^{2}}
$$

Keterangan:

$\mathrm{n}=$ jumlah sampel

$\mathrm{N}=$ jumlah populasi

$\mathrm{e}=$ batas ketelitian yang diinginkan

$$
\begin{aligned}
\mathrm{n} & =\frac{500}{1+200(0,05)^{2}} \\
& =222,22
\end{aligned}
$$

Jadi, berdasarkan perhitungan diatas, maka jumlah sampel adalah sebanyak 222. Dalam peneliti ini teknik sampel yang digunakan adalah teknik probability sampling dengan metode sistematis sampling. Sistematis sampling adalah metode sampling yang menggunakan nomor urut dari populasi baik yang berdasarkan nomor yang ditetapkan sendiri oleh peneliti maupun nomor identitas tertentu, ruang dengan urutan yang seragam atau pertimbangan sistematis lainnya (Sugiyono, 2009). Misalnya dari sampel diatas terdiri dari 222. Pengambilan sampel dapat dilakukan dengan nomor ganjil saja, genap saja, atau kelipatan dari bilangan tertentu, misalnya kelipatan dari bilangan tiga. Untuk itu maka yang diambil sampel adalah 3, 6, 9, 12 dan seterusnya sampai 222. Maka data dalam penelitian ini penulis dapat mengambil sampel sebanyak 111 karyawan. 


\subsection{Jenis dan sumber Data}

Jenis dan sumber data yang digunakan dalam penelitian ini adalah data primer. Dimana data primer adalah data yang di diperoleh dan dikumpulkan dari para karyawan kantor. Data primer ini diperoleh melalui penyebaran kuisioner kepada karyawan yang menjadi responden.

\subsection{Teknik Pengumpulan Data}

Sesuai dengan metode penelitian yang digunakan, yakni metode survei, maka untuk memperoleh data yang diperlukan dalam penelitian ini, pengumpulan data dilakukan dengan menggunakan metode-metode field research dan library research. Dalam kuisioner tersebut digunakan skala Liker tuntuk mengukur sikap, pendapat, dan persepsi seseorang atau sekelompok orang tentang fenomena sosial. Dengan skala Likert, maka variabel yang akan diukur dijabarkan menjadi indikator variabel. Kemudian indikator tersebut dijadikan sebagai titik tolak untuk menyusun item-item instrument yang dapat berupa pernyataan atau pertanyaan. Jawaban dari setiap item instrument yang menggunakan skala Likert mempunyai gradasi dari sangat positif sampai sangat negatif.

\subsection{Teknik Analisis Data}

Penelitian ini melihat hubungan yang terjadi independent variable dengan dependent variable melalui korelasi. Derajat atau tingkat hubungan antara dua variabel diukur dengan menggunakan indeks korelasi, yang disebut koefisien korelasi. Dalam penelitian ini digunakan teknik korelasi sederhana dan multiple-regression analysis. Koefisien-koefisien regresi distandarisasikan untuk mengurai hubungan antara dua variabel bebas dan satu variabel terikat. Dalam pengamatan dan penganalisaan serta pengukuran normalitas, setiap faktor akan dilihat hubungan melalui korelasi sederhana. Hubungan variabel bebas dan terikat secara keseluruhan akan ditinjau lebih jauh untuk mengetahui tingkatan korelasi yang multiple.

\section{Analisis dan Pembahasan}

\subsection{Analisis}

Metode pengolahan data yang digunakan pada penelitain ini adalah metode analisis deskriptif dan metode analisis inferensial. Metode analisis deskriptif adalah statistik yang digunakan untuk menganalisa data dengan cara mendeskripsikan atau menggambarkan data yang telah terkumpul sebagaimana adanya tanpa bermaksud membuat kesimpulan yang berlaku untuk digeneralisasikan. Termasuk dalam statistik deskriptif antara lain adalahpenyiapan data dalam bentuk tabel, grafik, perhitungan median, mean, standart deviasi, perhitungan prosentase, dan lain-lain (Sugiyono, 2009: 207). Adapun untuk kepentingan penelitian ini menggunakan program SPSS for window. Berdasarkan data variabel terikatnya (Y) adalah loyalitas karyawan dan variabel bebasnya adalah displin $\left(\mathrm{X}_{1}\right)$, budaya organisasi $\left(\mathrm{X}_{2}\right)$, dan motivasi kerja $\left(\mathrm{X}_{3}\right)$.

\subsubsection{Uji Validitas dan Reliabilitas}

Sebelum melakukan penyebaran kuesioner kepada responden, penulis melakukan percobaan penyebaran kuesioner kepada karyawan, untuk melakukan pengujian validitas dan reliabelitas. Jika nilai $r$ hitung yang merupakan nilai dari Corrected Item - Total Correlation $>$ dari $\mathrm{r}$ tabel maka dapat dinyatakan valid. Selanjutnya kuesioner tersebut akan digunakan dalam penelitian. Uji reliabilitas dapat dilakukan secara bersama-sama terhadap seluruh butir pertanyaan untuk lebih dari satu variabel, namun sebaiknya uji reliabilitas dilakukan pada masing-masing variabel pada lembar kerja yang berbeda sehingga dapat diketahui konstruk variabel mana yang tidak reliabel. Realibilitas suatu konstruk variabel dikatakan baik jika memiliki nilai Cronbach's Alpha $>$ dari 0, 60. 


\subsubsection{Uji Reliabilitas}

Berdasarkan hasil pengolahan data uji reliabilitas dapat dilihat pada tabel di bawah ini: Berdasarkan tabel di atas menunjukkan bahwa variabel displin $\left(\mathrm{X}_{1}\right)$, budaya organisasi $\left(\mathrm{X}_{2}\right)$, dan motivasi kerja $\left(\mathrm{X}_{3}\right)$ dan Loyalitas karyawan $(\mathrm{Y})$ diperoleh nilai Cronbach Alpha lebih besar dari nilai kritis $(0,60)$. Dengan demikian dapat disimpulkan bahwa semua variabel dapat dikatakan reliabel.

Tabel 4.1

Reliabilitas

\begin{tabular}{|l|c|c|c|}
\hline \multicolumn{1}{|c|}{ Variabel } & $\begin{array}{c}\text { Jumlah } \\
\text { Pernyataan }\end{array}$ & $\begin{array}{c}\text { Cronbach } \\
\text { Alpha }\end{array}$ & Keterangan \\
\hline Displin $\left(\mathrm{X}_{1}\right)$ & 10 & 0,916 & Reliabel \\
\hline Budaya Organisasi $\left(\mathrm{X}_{2}\right)$ & 10 & 0,843 & Reliabel \\
\hline Motivasi Kerja $\left(\mathrm{X}_{3}\right)$ & 10 & 0,832 & Reliabel \\
\hline Loyalitas Karyawan (Y) & 10 & 0,817 & Reliabel \\
\hline Sumber: Diolah Penulis (2016) & & &
\end{tabular}

\subsection{Pembahasan}

\subsubsection{Uji Asumsi Klasik}

Dalam melakukan analisa, penulis menggunakan perangkat lunak SPSS. Hasil dari analisa akan dibahas pada bagian berikut:

\section{Uji Normalitas}

Uji asumsi normalitas data yang digunakan dalam penelitian ini adalah menggunakan pendekatan grafis. Pengujian normalitas digunakan untuk melihat pola distribusi kekeliruan. Pengujian ini dapat dilakukan dengan jalan melihat grafik histogram kekeliruan yang berbentuk lonceng (distribusi normal) dan Normal $P$-P-plot.

\section{Gambar 4.1.}

\section{Hasil Uji Normalitas dengan P-P Plot}

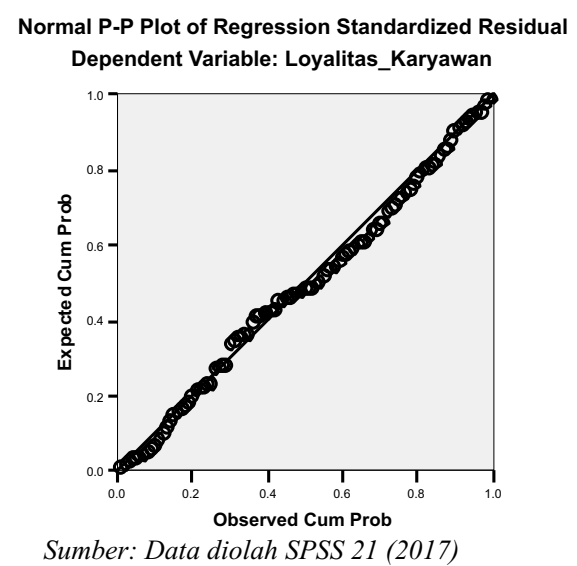

Dari gambar 4.1 di atas terlihat bahwa titik-titik atau data searah dan mengikuti garis diagonal. Hal ini dapat disimpulkan bahwa data terdistribusi normal, sehingga dapat melanjutkan ke uji asumsi klasik.

\section{Uji Multikolinearitas}

Dari tabel 4.2. dibawah dapat terlihat nilai tolerance dari variabel disiplin, budaya organisasi, dan motivasi kerja tidak ada yang menunjukkan di bawah $10 \%$ atau melihat Variance Inflation Factor 
(VIF) tidak ada yang lebih dari 10, maka dapat dikatakan bahwa model regresi ini dari variabelvariabel tersebut tidak ada masalah multikolinieritas atau Ho diterima.

Tabel 4.2

Hasil Uji Multikolinieritas dengan

VIF (Variance Inflation Factors)

Coefficients $^{\mathrm{a}}$

\begin{tabular}{|ll|r|c|}
\hline \multirow{2}{*}{ Model } & \multicolumn{2}{c|}{ Collinearity Statistics } \\
\cline { 3 - 4 } & Tolerance & \multicolumn{1}{c|}{ VIF } \\
\hline 1 & Disiplin & .785 & 1.274 \\
& Budaya_Organisasi & .724 & 1.381 \\
& Motivasi_Kerja & .802 & 1.248 \\
\hline
\end{tabular}

a. Dependent Variable: Loyalitas_Karyawan

Sumber: Data diolah SPSS 21 (2017)

\section{Uji Heteroskedastisitas}

\section{Gambar 4.2}

Hasil Uji Heteroskedastisitas dengan Scatterplot scaterplot

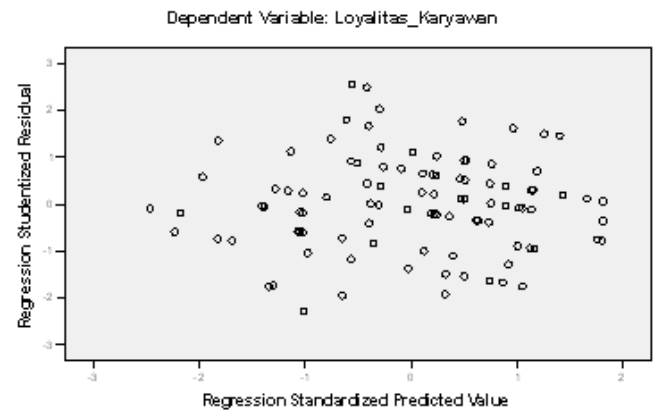

Sumber: Data diolah SPSS 21 (2017)

Dari gambar 4.2. di atas terlihat bahwa titik-titik menyebar secara acak serta tersebar baik di atas maupun di bawah angka 0 pada sumbu Y. Hal ini dapat disimpulkan bahwa tidak terjadi heteroskedastisitas pada model regresi, sehingga model regresi layak dipakai untuk memprediksi loyalitas karyawan berdasarkan masukkan variabel bebas disiplin, budaya organisasi, dan motivasi kerja.

\subsubsection{Analisis Regresi Berganda}

Jenis regresi yang digunakan adalah regresi berganda, karena memiliki lebih dari satu variabel independen. Dan Model regresinya adalah sebagai berikut: $Y=a+b_{1} X_{1}+b_{2} X_{2}+b_{3} X_{3}+e$

Loyalitas Karyawan $=13,590+0,466 \mathrm{X}_{1}+0,307 \mathrm{X}_{2}+0,214 \mathrm{X}_{3}+\mathrm{e}$

Keterangan:

$\mathrm{Y}=$ Loyalitas Karyawan

$\mathrm{a}=$ Konstanta

$\mathrm{b}_{1}=$ Parameter $\mathrm{X}_{1}$

$\mathrm{b}_{2}=$ Parameter $\mathrm{X}_{2}$

$\mathrm{b}_{3}=$ Parameter $\mathrm{X}_{3}$

$\mathrm{X}_{1}=$ Disiplin

$\mathrm{X}_{2}=$ Budaya organisasi

$\mathrm{X}_{3}=$ Motivasi Kerja

$\mathrm{e}=$ error 
Tabel 4.3

Hasil Output Analisis Regresi Berganda

Coefficients ${ }^{2}$

\begin{tabular}{|c|c|c|c|c|c|c|}
\hline \multirow{2}{*}{\multicolumn{2}{|c|}{ Model }} & \multicolumn{2}{|c|}{$\begin{array}{c}\text { Unstandardized } \\
\text { Coefficients }\end{array}$} & \multirow{2}{*}{$\begin{array}{c}\begin{array}{c}\text { Standardized } \\
\text { Coefficients }\end{array} \\
\text { Beta }\end{array}$} & \multirow[b]{2}{*}{$t$} & \multirow[b]{2}{*}{ Siq. } \\
\hline & & $B$ & Std. Error & & & \\
\hline \multirow[t]{4}{*}{1} & (Constant) & 13.590 & 6.910 & & 1.967 & .052 \\
\hline & Disiplin & .466 & .101 & .443 & 4.602 & .000 \\
\hline & Budaya_Organisasi & .307 & .125 & .425 & 4.461 & .000 \\
\hline & Motivasi_Kerja & .214 & .140 & .392 & 3.529 & .000 \\
\hline
\end{tabular}

a. Dependent Variable: Loyalitas_Karyawan

Sumber: Data diolah SPSS 21 (2017)

Persamaan regresi di atas berarti sebagai berikut:

1. Koefisien regresi variabel disiplin sebesar 0,466 menyatakan bahwa jika disiplin mengalami kenaikan satu satuan, maka loyalitas karyawan akan mengalami kenaikan sebesar 0,466 satu satuan dengan asumsi variabel bebas lainnya bernilai tetap.

2. Koefisien regresi variabel budaya organisasi sebesar 0,307 menyatakan bahwa jika budaya organisasi mengalami kenaikan satu satuan, maka loyalitas karyawan akan mengalami kenaikan sebesar 0,307 satu satuan dengan asumsi variabel bebas lainnya bernilai tetap.

3. Koefisien regresi variabel motivasi kerja sebesar 0,214 menyatakan bahwa jika motivasi kerja mengalami kenaikan satu satuan, maka loyalitas karyawan akan mengalami kenaikan sebesar 0,214 satu satuan dengan asumsi variabel bebas lainnya bernilai tetap.

\subsubsection{Uji Korelasi dan Koefisien Determinasi}

Uji regresi digunakan untuk mengetahui pengaruh antara variabel bebas, yaitu disiplin, budaya organisasi, dan motivasi kerja terhadap variabel terikat yaitu loyalitas karyawan.

Tabel 4.4

Koefisien Korelasi dan Determinasi

Model Summary

\begin{tabular}{|l|r|r|r|r|}
\hline Model & R & R Square & $\begin{array}{c}\text { Adjusted } \\
\text { R Square }\end{array}$ & $\begin{array}{r}\text { Std. Error of } \\
\text { the Estimate }\end{array}$ \\
\hline 1 & $.847^{\mathrm{a}}$ & .717 & .620 & 3.40518 \\
\hline
\end{tabular}

a. Predictors: (Constant), Motivasi_Kerja, Disiplin, Budaya_Organisasi

b. Dependent Variable: Loyalitas_Karyawan

Sumber: Data diolah SPSS 21 (2017)

Pada tabel 4.4. di atas besarnya nilai koefisien korelasi (r) sebesar 0,847 yang berarti menunjukkan adanya korelasi/hubungan yang sangat kuat antara disiplin, budaya organisasi, dan motivasi kerja dengan loyalitas karyawan. Besarnya nilai adjusted coeficient of determination (adjusted $\mathrm{R}^{2}$ ) adalah 0,620 atau $62 \%$ yang berarti variabel-variabel bebas dapat menerangkan perubahan pada variabel loyalitas karyawan sebesar $62 \%$ sedangkan sisanya sebesar 38\% diterangkan oleh faktor-faktor lain diluar penelitian ini. 


\subsubsection{Uji Hipotesis}

\section{Ujit}

Uji t digunakan untuk menguji apakah terdapat pengaruh yang signifikan antara variabel bebas terhadap variabel terikat secara terpisah.

Kriteria pengujian:

$\mathrm{H}_{0}$ diterima jika nilai Sig (Probabilitas) $>0,05$

$\mathrm{H}_{0}$ ditolak jika nilai Sig (Probabilitas) $<0,05$

\section{Tabel 4.5}

Hasil Uji t

Coefficients $^{\mathrm{a}}$

\begin{tabular}{|c|c|c|c|c|c|c|}
\hline & & \multicolumn{2}{|c|}{$\begin{array}{c}\text { Unstandardized } \\
\text { Coefficients }\end{array}$} & \multirow{2}{*}{$\begin{array}{c}\begin{array}{c}\text { Standardized } \\
\text { Coefficients }\end{array} \\
\text { Beta }\end{array}$} & \multirow[b]{2}{*}{$t$} & \multirow[b]{2}{*}{ Siq. } \\
\hline \multicolumn{2}{|c|}{ Model } & B & Std. Error & & & \\
\hline & (Constant) & 13.590 & 6.910 & & 1.967 & .052 \\
\hline & Disiplin & .466 & .101 & .443 & 4.602 & .000 \\
\hline & Budaya_Organisasi & .307 & .125 & .425 & 4.461 & .000 \\
\hline & Motivasi_Kerja & .214 & .140 & .392 & 3.529 & .000 \\
\hline
\end{tabular}

a. Dependent Variable: Loyalitas_Karyawan

Sumber: Data diolah SPSS 21 (2017)

Dari hasil uji t tabel 4.5 diatas dapat disimpulkan bahwa seluruh dari variabel displin, budaya organisasi dan motivasi kerja berpengaruh secara signifikansi terhadap variabel loyalitas karyawan dapat dilihat tingkatan signifikansi yang lebih kecil dari 0,05

\section{Uji F}

Uji F digunakan untuk menguji apakah terdapat pengaruh yang signifikan antara variabel bebas terhadap variabel terikat secara bersama-sama.

Kriteria pengujian:

$\mathrm{H}_{0}$ diterima jika nilai Sig (Probabilitas) $>0,05$

$\mathrm{H}_{0}$ ditolak jika nilai Sig (Probabilitas) $<0,05$

Tabel 4.6

Hasil Uji F

ANOVA $^{\text {b }}$

\begin{tabular}{|ll|c|r|r|r|r|}
\hline \multicolumn{1}{|c|}{} & \multicolumn{1}{c}{$\begin{array}{c}\text { Sum of } \\
\text { Model }\end{array}$} & & & & \\
\hline 1 & & Squares & df & Mean Square & F & Siq. \\
\hline & Regression & 317.604 & 3 & 105.868 & 29.130 & $.000^{\text {a }}$ \\
& Total & 1113.146 & 96 & 11.595 & & \\
& 1430.750 & 99 & & & \\
\hline
\end{tabular}

a. Predictors: (Constant), Motivasi_Kerja, Disiplin, Budaya_Organisasi

b. Dependent Variable: Loyalitas_Karyawan

Sumber: Data diolah SPSS 21 (2017)

Dari tabel 4.6 di atas dapat terlihat bahwa nilai Fhitung sebesar 29,130 dengan probabilitas 0,000, karena probabilitasnya lebih kecil dari 0,05 , maka model regresi dapat digunakan untuk memprediksi loyalitas karyawan. Hal ini juga dapat dilihat dari Fhitung $>$ Ftabel $(29,130>2,70)$, maka Ho ditolak atau Ha diterima yang berarti bahwa ada hubungan positif dan pengaruh signifikan secara simultan (bersama-sama) dari variabel disiplin, budaya organisasi, dan motivasi kerja secara bersama-sama terhadap variabel loyalitas karyawan. 


\section{Simpulan dan Saran}

\subsection{Simpulan}

Berdasarkan hasil penelitian dan pembahasan yang telah dikemukakan sebelumnya, maka diperoleh kesimpulan sebagai berikut:

1. Hasil uji secara parsial untuk variabel disiplin dengan nilai statistik thitung $>$ ttabel $(4,602>$ 1,985 ) serta nilai probabilitas sebesar $0,000<0,05$, maka Ho ditolak berarti ada hubungan positif dan pengaruh signifikan dari variabel disiplin terhadap loyalitas karyawan.

2. Hasil uji secara parsial untuk variabel budaya organisasi dengan nilai statistik thitung $>$ ttabel $(4,461>1,985)$ serta nilai probabilitas sebesar $0,000<0,05$, maka Ho ditolak berarti ada hubungan positif dan pengaruh signifikan dari variabel budaya organisasi terhadap loyalitas karyawan.

3. Hasil uji secara parsial untuk variabel motivasi kerja dengan nilai statistik thitung $>$ ttabel $(3,529>1,985)$ serta nilai probabilitas sebesar $0,000<0,05$, maka Ho ditolak berarti ada hubungan positif dan pengaruh signifikan dari variabel motivasi kerja terhadap loyalitas karyawan.

4. Hasil uji secara simultan dengan nilai Fhitung $>$ Ftabel $(29,130>2,70)$, maka Ho ditolak atau Ha diterima yang berarti bahwa ada hubungan positif dan pengaruh signifikan secara simultan (bersama-sama) dari variabel disiplin, budaya organisasi, dan motivasi kerja secara bersamasama terhadap variabel loyalitas karyawan. Besarnya nilai koefisien korelasi (r) sebesar 0,847 yang berarti menunjukkan adanya korelasi/hubungan yang sangat kuat antara disiplin, budaya organisasi, dan motivasi kerja dengan loyalitas karyawan. Besarnya nilai adjusted coeficient of determination (adjusted $\mathrm{R}^{2}$ ) adalah 0,620 atau $62 \%$ yang berarti variabel-variabel bebas dapat menerangkan perubahan pada variabel loyalitas karyawan sebesar $62 \%$ sedangkan sisanya sebesar 38\% diterangkan oleh faktor-faktor lain diluar penelitian ini.

\subsection{Saran}

Berdasarkan analisis dan pembahasan yang dilakukan terhadap jawaban responden bahwa disiplin, budaya organisasi, dan motivasi kerja berpengaruh secara signifikan terhadap loyalitas karyawan, namun ada beberapa hal yang penulis sarankan untuk terus meningkatkan loyalitas karyawan melalui beberapa hal, yaitu:

1. Disiplin kerja yang sudah ada agar lebih ditingkatkan agar karyawan merasa memiliki perusahaan sehingga mereka akan loyal terhadap perusahaan.

2. Perusahaan yang baik adalah perusahaan yang memiliki budaya kerja yang baik, sehingga dengan budaya kerja yang baik, maka karyawan akan merasa menjadi bagian dari perusahaan.

3. Dengan diperhatikannya karyawan, sehingga mereka termotivasi dalam meningkatkan kinerja kerjanya.

4. Untuk penelitian lebih lanjut, penulis menyarankan agar menambah variabel yang sudah penulis teliti dan menentukan responden yang lebih selektif, serta jumlah respondennya lebih diperbanyak.

\section{Daftar pustaka}

Hamidi, 2007. Metode Penelitian dan Teori Komunikasi. UMM Press. Malang. Handoko, T, Hani. 2009. Manajemen Personalia dan Sunber Daya Manusia. Rajawali Pers. Jakarta. Hayes, Harter Schmid. 2012. Perilaku Manajemen Sumber Daya Manusia. EdisiRevisi. Salemba Empat. Jakarta.

Hasibuan, Malayu SP. 2012. Manajemen Sumber Daya Manusia. BumiAksara. Jakarta.

Pambudi, Rengku. Ragil. 2010. Riset Sumber Daya Manusia. Gramedia Pustaka Umum. Jakart 
Mangkunegara, Anwar Prabu .2010. Manajemen Sumber Daya Manusia Perusahaan. Buku Kesatu dan Kedua. Salemba Empat. Jakarta.

Priyatno, Duwi. 2013. Mandiri Belajar Analisis Data Dengan SPSS. Mediakom. Yogyakarta

Schein, Edgar. 2010. Perilaku dan Budaya Organisasi. Salemba Empat. Jakarta.

Sinungan, Muchdarsyah. 2006. Metode Penelitian Manajemen. PT RinekaCipta. Jakarta.

Sugiyono, 2009. Metode Penelitian Kualitatif dan Kuantitatif. Alfhabeta. Bandung

Supardi, Anwar. 2005. Pengantar Ilmu Komunikasi. PT Raja GrafindoPersada. Jakarta.

Sutrisno, Edy. 2010. Manajemen Sumber Daya Manusia. KencanaPeranada Media Grup. Jakarta.

Suwatno, 2003. Azas-Azas Manajemen Sumber Daya Manusia. Gramedia Pustaka Utama. Jakarta.

Utomo, Poerwopoespito. 2010. Psychological testing Principles application. BPFE. Yogyakarta.

Wibawa, I, Made, Artha. 2010.Pengaruh Kompensasi dan Lingkungan Kerja Pada Loyalitas Karyawan Berdasarkan Jenis Kelamin. Universitas Udayana. Bali .portalgaruda.org/article. Jurnal. (20/01/2017).

Wijayanti, Irine, Diana, Sari. 2008. Manajemen. Mitra Cendika. Yogyakarta. 